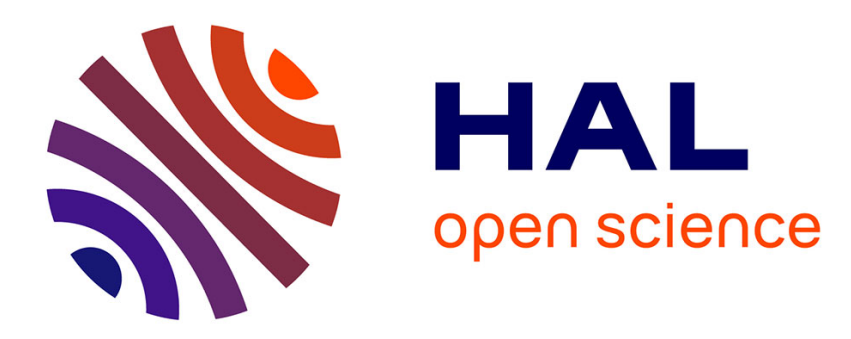

\title{
Traces of Appropriation: Roman Board Games in Egypt and Sudan
}

Alex de Voogt

\section{To cite this version:}

Alex de Voogt. Traces of Appropriation: Roman Board Games in Egypt and Sudan. Archimède: archéologie et histoire ancienne, 2019, 6, pp.89-99. halshs-02895539

\section{HAL Id: halshs-02895539 \\ https://shs.hal.science/halshs-02895539}

Submitted on 9 Jul 2020

HAL is a multi-disciplinary open access archive for the deposit and dissemination of scientific research documents, whether they are published or not. The documents may come from teaching and research institutions in France or abroad, or from public or private research centers.
L'archive ouverte pluridisciplinaire HAL, est destinée au dépôt et à la diffusion de documents scientifiques de niveau recherche, publiés ou non, émanant des établissements d'enseignement et de recherche français ou étrangers, des laboratoires publics ou privés. 


\section{ARCHIMĖDE No6

1 DOSSIER THÉMATIQUE :

HISTOIRES DE FIGURES CONSTRUITES : LES FONDATEURS DE RELIGION

DOSSIER THÉMATIQUE :

JOUER DANS L'ANTIQUITÉ : IDENTITÉ ET MULTICULTURALITÉ

GAMES AND PLAY IN ANTIQUITY: IDENTITY AND MULTICULTURALITY

71 Véronique DASEN et Ulrich SCHÄDLER

Introduction

\section{EGYPTE}

75 Anne DUNN-VATURI

Aux sources du « jeu du chien et du chacal »

89 Alex DE VOOGT

Traces of Appropriation: Roman Board Games in Egypt and Sudan

100 Thierry DEPAULIS

Dés coptes ? Dés indiens?

MONDE GREC

113 Richard. H.J. ASHTON

Astragaloi on Greek Coins of Asia Minor

127 Véronique DASEN

Saltimbanques et circulation de jeux

144 Despina IGNATIADOU

Luxury Board Games for the Northern Greek Elite

160 Ulrich SCHÄDLER

Greeks, Etruscans, and Celts at play

MONDE ROMAIN

175 Rudolf HAENSCH

Spiele und Spielen im römischen Ägypten: Die Zeugnisse der verschiedenen Quellenarten

186 Yves MANNIEZ

Jouer dans l'au-delà ? Le mobilier ludique des sépultures de Gaule méridionale et de Corse ( $V^{\text {e }}$ siècle av. J.-C. - Ve siècle apr. J.-C.)

199 Mark Anthony HALL

Whose Game is it Anyway? Board and Dice Games as an Example of Cultural Transfer and Hybridity 


\title{
TRACES OF APPROPRIATION: ROMAN BOARD GAMES IN EGYPT AND SUDAN
}

\author{
Alex DE VOOGT \\ Associate Professor \\ Drew University \\ adevoogt@drew.edu
}

\section{ABSTRACT}

Board games in antiquity are characterized by their continuity in both shape and playing practice when crossing socio-political borders and centuries of time. But as much as these games appear similar throughout the archaeological record, traces of integration and appropriation are found in aspects not necessarily affecting rules of play or configurations of boards.

ecently uncovered examples of the game of Duodecim scripta in Egypt and Sudan point to changes in board design or, at least, in design preference when compared to those found elsewhere in the Roman Empire. The presence of game boards in grave contexts further illustrates the extent of the appropriation that may have taken place.

Egypt and Sudan in GrecoRoman times are on and across the border of the

\section{KeYWORDS}

Cultural appropriation, cultural transmission, Duodecim scripta,

Egypt,

Sudan.
Roman world and provide ideal contexts for the understanding of the cultural appropriation process of board games in antiquity.
Les jeux de plateau dans l'Antiquité se caractérisent par leur continuité au niveau de la morphologie et des pratiques ludiques à travers les frontières socio-politiques et les siècles. Cependant, bien que ces jeux démontrent une homogénéité au sein du matériel archéologique, des éléments d'intégration et d'appropriation se manifestent par certains aspects qui n'influencent pas nécessairement les règles ou les configurations des plateaux.

Des exemples du jeu de Duodecim scripta découverts récemment en Égypte et au Soudan, indiquent des changements dans la conception du plateau, ou du moins, dans le choix du modèle par comparaison avec d'autres exemples mis au jour dans le reste de l'empire romain. De plus, la présence de plateaux de jeu en contexte funéraire illustre l'importance du processus d'appropriation qui s'est déroulé.

L'Égypte et le Soudan à l'époque gréco-romaine se situent à la fois à cheval et au-delà des frontières du monde romain ce qui fournit des contextes exemplaires pour la compréhension des processus d'appropriation culturelle des jeux de plateau dans l'Antiquité.
MOTS-CLÉs

Appropriation culturelle, transmission culturelle, Duodecim scripta, Égypte, Soudan. 


\section{MATERIAL AND PRACTICE}

Board games have both a material and a practice associated with their existence. Their material complexity makes them stand out in the archaeological record as game boards, pieces and dice exhibit physical characteristics that serve a specific purpose when playing the game and which are often diagnostic for the archaeologists when identifying the type of game. Configurations of playing fields, sets of gaming pieces and the number or absence of dice are constituent parts of a gaming practice that crosses borders largely unchanged. The practice of playing board games mainly includes the rules of play for which evidence exists primarily in the literary sources. The combination of physical and literary sources reveal a cultural trait [1] as well as acting as a "social lubricant" [2] that facilitates interaction on the border between cultures. The games provide evidence of millennia-long traditions that outlived many a state and political organization. It is as if board games, or at least important aspects of what makes a board game, remain largely impervious to outside cultural and socio-political influences and pressures.

Board games are also made of specific materials, such as wood, bone or stone, which may be particular to a region. The physical objects may be decorated in individual or regional styles and placed in contexts that are relevant for understanding the cultural and socio-political significance of the people associated with the game or of the objects themselves. The playing practice may be depicted on murals or in mosaics providing a context for clothing, gender, furniture and language. These contexts are specific to a period, an individual or a group of people, and change with the times as well as with place. These aspects that are particular to a time or place can also be seen as part and parcel of a board game even if they rarely affect the rules of play (other than perhaps the rules of conduct). While intuitively board game historians know which aspect of a board game is or is not sensitive to this socio-cultural environment, making this distinction explicit helps to understand how a board game is most likely appropriated by another culture and at the same time how unlikely.

As a result, it is not surprising and quite acceptable to archaeologists to find that rules for a game in antiquity obtained from just one literary ancient source are generalized. They are seen as appropriate for all game boards with a similar configuration and with similar gaming implements even if these examples are many centuries and many miles apart. For instance, a cuneiform tablet with the rules for the game of twenty squares is generally assumed to be a reliable document for most twenty square games found in over fifteen hundred years across the Near East and Egypt [3]. Even if the rules of play are presumed identical, it needs to be stressed that the design, such as the shape of playing boards and playing spaces, is not necessarily uniform across time and space. Ulrich Schädler has shown that the game of five lines is not only found as five lines but also as two rows of five squares and even two rows of five holes or cup-shaped depressions in Roman Asia Minor, while he still assumes that the playing rules are largely the same [4].

Games scratched in stone or marble surfaces have potentially fewer variable features than portable game boards that add a third dimension, often the addition of adornment to the base or box on which they are found. For example, in ancient Egypt prior to the Roman occupation multiple decorated Senet game boards from tombs point to the "international style", a set of artistic conventions common through the Near East and Aegean worlds. [5]. Since a significant number of Roman games have been found scratched in a surface rather than as three-dimensional objects, variation is limited. A late-antique gaming table for Duodecim scripta at the baths of Hadrian at Aphrodisias [6] is a rare exception with a Greek inscription flanking the far end of the board that is, nevertheless, carved as an unmovable object.

[1] Crist \& Dunn-Vaturi \& De Voogt \& Eerkens, 2013: $1715-1730$.

[2] Crist \& De Voogt \& Dunn-Vaturi, 2016: $179-196$.

[3] FINKEL 2007: 16-32.

[4] SCHÄDLER 1998: 10-25.

[5] CRist \& Dunn-Vaturi \& De Voogt, 2016: 89-91.

[6] SCHÄDLER 2000, cover photograph. 


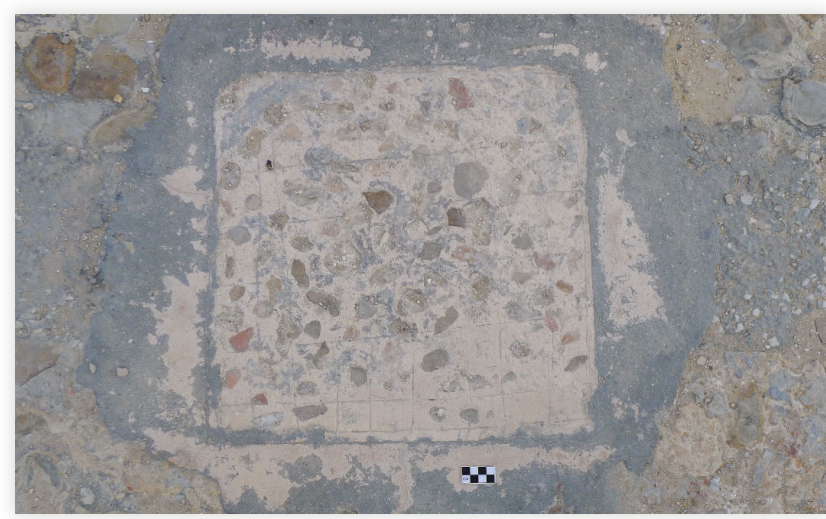

A Figure 1a. First example of a Latrunculus board at the Antonine Baths at Carthage, Tunisia. Photo by Alex De Voogt 2011

$>$ Figure 1b. Context of the first example of a Latrunculus board. Photo by Alex DE Voogt 2011.

$\checkmark$ Figure 1c. Second example of a Latrunculus board at the Antonine Baths at Carthage, Tunisia. Photo by Alex De Voogt 2011.

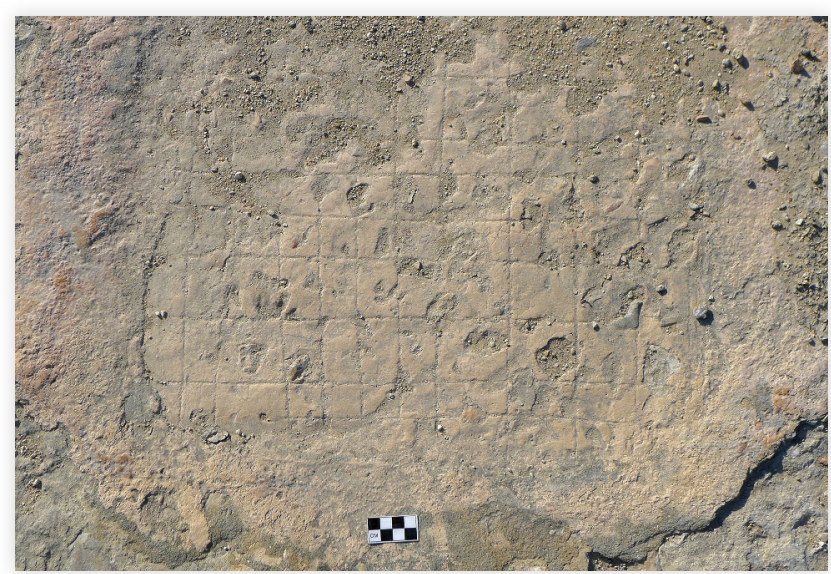

The generic shape of a playing board may offer little information as to the appropriation of game board design. For instance, the Latrunculi boards in the Antonine Baths at Carthage are difficult to ascribe to this region by observing the design of the boards (fig. 1a, 1b, 1c); there seems to be too little variation possible when carving squares to make regional variation likely. In contrast, the most elaborate carving of a Roman game is probably the game of Duodecim scripta, a predecessor of today's backgammon game, of which the remains may consist of a few lines or of elaborate rows of markings (fig. 2) or letters, all elements that greatly assist its identification.

One Duodecim scripta board found at a public bath in Rome has a text with a Christian invocation carved across the full length of the board that reads: "To the players of dice Jesus Christ gives assistance and victory, and also to those who write their own name when they play with dice" [7]. Such an explicit appropriation, in this case by a Christian tradition,

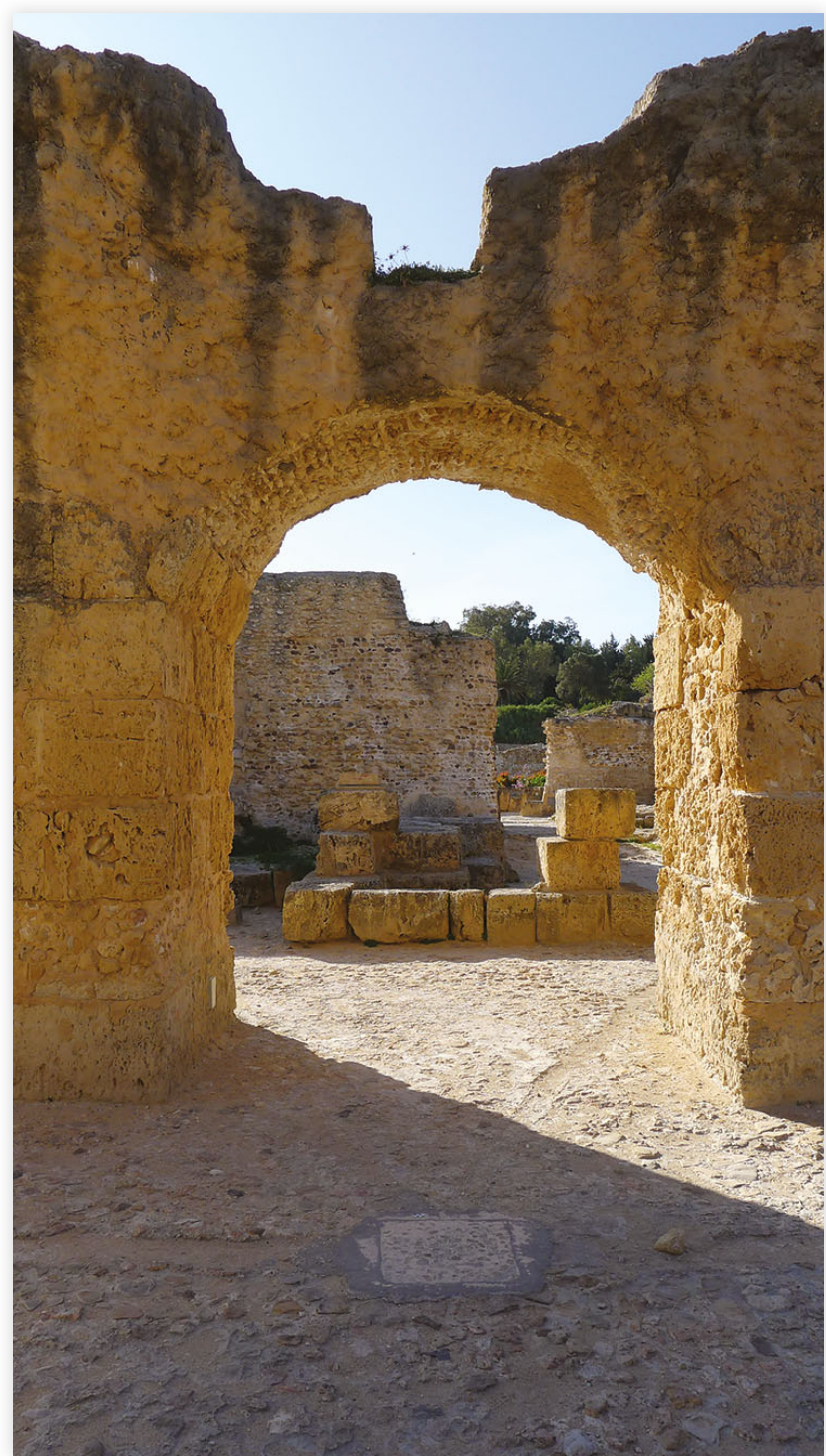

is particularly valuable as text often tells us more than board design. The most common appearance of Duodecim scripta in the Roman Empire is as a set of letters that together read as a hexameter. However, the appropriation of such a tradition outside the Roman Empire would require an appreciation of Roman script and language as well as a propensity for adding textual elements to objects.

The following investigation into the possible appropriation of the Roman game of Duodecim scripta in Egypt and Sudan, and into aspects that relate to the identity of the players, concentrates on two elements. First, the context in which the boards were found. Two burial contexts have provided examples of Duodecim scripta in Nubia while in Egypt several boards were carved in rock faces or found as a stone-carved board within a built environment. These contrasting

[7] Translation after BEDON 1989: 60. 


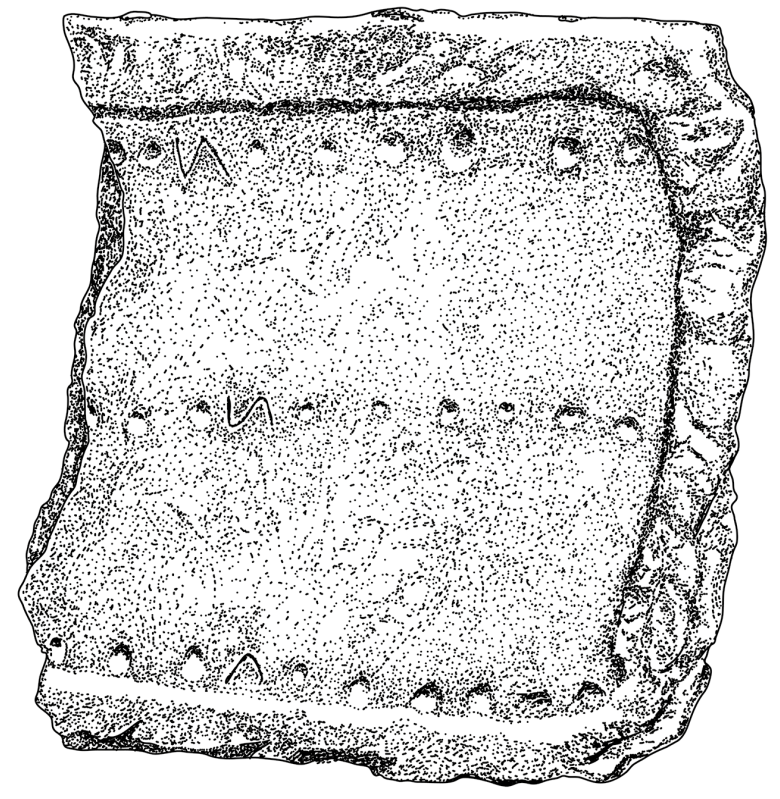

A Figure 2.

Drawing of the partial Duodecim scripta board from Dawwi, Egypt. Drawing by Jennifer STEFFEY after BRUN 2003.

contexts are compared to those elsewhere in or near the Roman Empire. Second, the designs of the respective boards seem to deviate from the common form for this game. For instance, the hexameter design is not attested at all in the region of Egypt and Sudan while square playing fields and enlarged mid-board markings adorn the boards in this region. Both context and design of Duodecim scripta boards may point to elements of cultural identity and specificity.

\section{IMAGERY AND VOTIVE CONTEXTS OF DUODECIM SCRIPTA}

Duodecim scripta boards in funerary contexts take on different forms. They may be votive objects, for instance, but in those cases the identification of the game presents its own challenges. For instance, a bronze mirror with an engraved design showing a young man and a woman playing a board game was once thought to represent a game of Duodecim scripta. The object is on display in the British Museum [8] and has been used in various publications to illustrate the game in progress [9]. Representations of this kind are complicated by the lack of detail provided for the game board, the main diagnostic feature, and Ulrich Schädler has shown this image to be of the game of five lines rather than Duodecim scripta [10].

It seems more common to find depictions of Achilles and Ajax playing with dice than images of any other board game scene in Greco-Roman times, as these men were part of a common trope on ancient Greek vases of which more than five hundred examples exist [11]. Also, various images of people playing Latrunculi have been attested [12] but considerably fewer, if any, concerning the game of Duodecim scripta. This absence makes a more thorough review of its other contexts all the more relevant.

Funerary objects concerning Duodecim scripta seem common on the fringes of the Roman Empire. An important exception is a large number of these game boards used to cover graves in the catacombs of Rome. These latter boards have been interpreted as part of a Christian tradition [13] rather than a Roman idea to include game boards in grave design. Instead the majority of Roman examples have been attested in public areas, mostly carved in a stone floor or sitting area [14].

There are a few votive examples that allude to a wider significance of the board game image. In the sanctuary of Mount St Angelo in Terracina, Italy, there was a votive offering for the goddess Venus dating to the second half of the second century CE [15]. Among the thirty-one miniature objects, often associated with children's graves, there was one gaming table with a representation of Duodecim scripta featured on top. A miniature portraying a Latrunculi game in progress was found in the Fayum in Egypt and is now located in the collections of the Petrie Museum [16]. Miniature objects are often interpreted as votive and their presence in both Egypt and other parts of the Roman Empire suggests that this use of board games did not necessarily change across borders. Unfortunately, such examples are rare and no such imagery is found for either Egypt or Sudan in reference to Duodecim scripta. In a detailed study of Roman gaming materials in free Germania, Thomas Krüger provided a rare example of a preserved wooden Duodecim scripta board [17]. The board showed a configuration for Duodecim scripta on
[8] Catalogue number 1898: 0716.4.

[9] E.g., MAY 1992: 166-189, in particular 179.

[10] SCHÄDLER 2012: 62.

[11] E.g., MAY 1992: 166-189, in particular 166-173. [12] Ibid.: 176.
[13] RIECHE 1984.

[14] E.g., SCHÄDLER 1995: 73-98.

[15] SCHÄDLER 2013: 23.

[16] Catalogue number UC59258. See CRIST \& DUNNVATURI \& DE VOOGT, 2016: 139.

[17] KRÜGER 1982. 
one side and a presumed Latrunculi board on the other. It was found in Vimose, present-day Denmark, outside the Roman Empire. The game board and many of the gaming pieces were found in bogs and excavated in the late 1850 s and 60 s; these deposits were common in the early Iron Age and largely coincide with the first centuries $B C E$ and $C E$ [18]. The finds frequently consisted of weapons but also included vessels, belt fittings, combs, beads, animal bones, idols, white stones, sticks of ash wood as well as dice and game pieces. The non-military materials have been interpreted in different ways; for instance, as deposits for fertility rituals [19]. These non-military deposits occurred prior to the Roman era but the locations "seem to be in continual use well into the Roman Iron Age" [20]. Weapon deposits started around the birth of Christ and during the second century they developed into so-called booty sacrifices where objects were deliberately destroyed and disposed of. The non-military deposits that included gaming materials seem separate from these and were not ritually destroyed. What stands out is that they were offerings made in wetlands, sometimes found near remains of wooden platforms where offering rituals may have taken place. In the words of Xenia Jensen: "the meetings between Roman and Germanic led to much more than a mindless adaption of foreign goods and ideas" [21].

In Leuna, Germany, also dating to the late Roman period, a particularly rich grave was excavated that included the remains of a double-sided wooden board as well as gaming pieces [22]. Although much less of the board was left compared to the one found at Vimose, games on both sides could be identified with reasonable certainty based on the number of playing pieces and the partial but diagnostic wooden remains. In this elaborate grave, the board was placed at the feet of the deceased next to a range of objects that included an ivory box, silver platters, glassware and bronze dishes. It was just outside the disturbed part of the tomb that was plundered [23] so that the game pieces were left in situ, giving some information about the size of the board and the possible games. A half-circle shape ornament inlaid with bronze was found at the position where Duodecim scripta boards often have a decorated divider in the center of the playing area [24].

Ulrich Schädler, in a publication about a game found in the so-called Doctor's burial in Britain, summarizes a list of excavations of graves dating to Roman times with remnants of game-boards with handles [25]. Many have associated game pieces but few have any part of the board left other than the metal hinges; the wood rarely survives. His table of gaming counters associated with cremation and inhumation burials in Britain clearly shows that glass and bone gaming pieces are not rare in burials in Britain whether or not they are associated with any particular game board. Rather, there seems sufficient archaeological evidence to regard board games as status symbols in Iron Age and Roman Britain. This evidence from Britannia and Germania presents a general context for the examples found in Nubian graves. First, it is not uncommon to find game boards, including Duodecim scripta, as part of grave goods or associated with ritual offerings elsewhere in Europe during Roman times. Most cases pertain to the areas on or across the border from the Roman Empire as is the case in Nubia. Second, the examples generally pertain to elite graves or contexts associated with the higher echelons of society with a valuable array of associated materials.

\section{FUNERARY MATERIAL FROM SEDEINGA, NUBIA}

In the Ptolemaic (332 BCE -30 BCE) and Roman (30 BCE - $395 \mathrm{CE}$ ) period Egypt bordered the Meroitic Kingdom in the south. This kingdom was located in Upper Nubia, Sudan, and a continuation of earlier civilizations. The Meroites fought with their northern neighbors so that the border between Egypt and Lower Nubia shifted regularly between the rise of the Meroites around $350 \mathrm{BCE}$ and their demise in the mid-fourth century CE [26]. What can be said with certainty is that one of the main centers of the Meroitic Kingdom in the north was never conquered by the Romans. This large settlement, known today as Sedeinga, has an extensive necropolis, which is still being excavated.

The first excavation of Meroitic Sedeinga took place in the early 1960s. Although searching for a necropolis of Egyptian elites, an Italian archaeological team excavated a group of rich Meroitic graves in Sedeinga [27]. The material included several objects
[18] JENSEN 2009.

[19] STJERNQUIST 1998: 157-178.

[20] JENSEN 2009: 56.

[21] JENSEN 2013: 182.

[22] SchULZ 1953: 29, 63-66, pl. XXVII-XXVIII.
[23] Ibid., 22, 24.

[24] Ibid., 29.

[25] SCHÄDLER 2007: 359-375.

[26] TÖRÖK 2009.

[27] See De Voogt \& Francigny \& BaAs 2017: 23-33. 

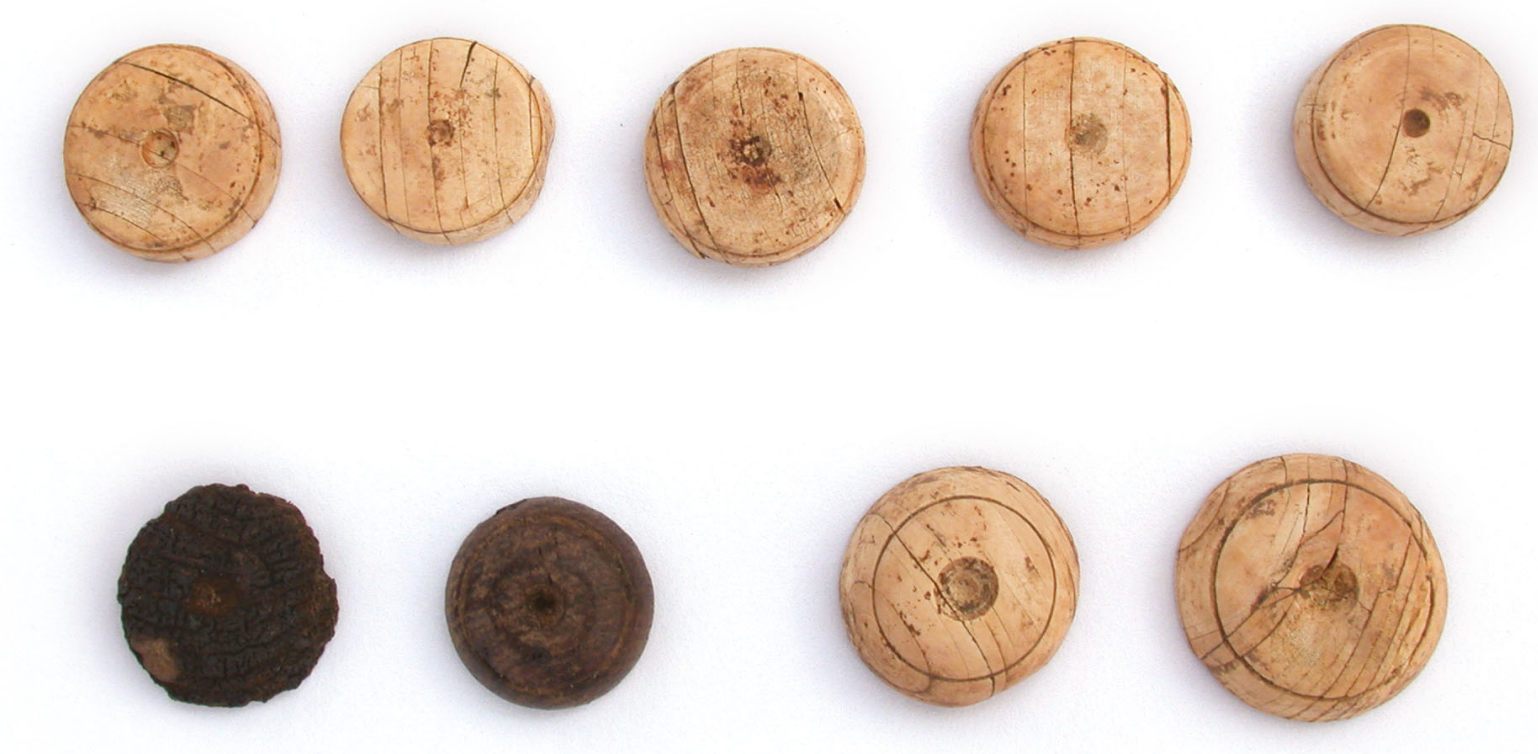

A Figure 3.

A selection of ivory and wooden playing pieces, Sedeinga, Sudan. Courtesy Sedeinga Mission.

of clear Greco-Roman origin or influence. Two graves contained large sets of gaming pieces, one in ivory and wood, the other in glass. The first also contained several ivory squares and remnants of a wooden gaming box. Both tombs further provided sets of cubic dice with the traditional 6-1, 2-5, 3-4 configuration. The game pieces and dice were partly published but the playing squares remained unpublished and were interpreted as part of a "draughts" board [28].

The identification of this material as two likely Duodecim scripta games is only a recent one and based largely on the number of gaming pieces and playing squares as well as the Greco-Roman influence shown by the remainder of the grave goods (fig. 3). The details of this find are part of a different study [29] but if we assume that the analysis is correct and that they are two Duodecim scripta games, it provides a rich context to investigate the appropriation that may have taken place across the border into the Meroitic Kingdom. This process has been studied by László Török but his work does not so far include the study of games [30].

In this grave, there was a gaming box showing a wooden board inlaid with ivory squares. It is unclear

[28] LECLANT 1966: 161-165; SCHIFF GioRgini 1966: 244-261.

[29] De VoOgt \& FRANCIGNY \& BAAS 2017.

[30] TÖRÖK 2011.

[31] Crist \& Dunn-Vaturi \& De Voogt 2016. if there was a game on the opposite side of the box as well. This presents one of few wooden Duodecim scripta examples of this kind. The gaming pieces, whether wood, ivory or glass, are also attested elsewhere in the Roman world as well as the cubic dice. The preservation of the gaming squares can be seen as an artifact of archaeology rather than a characteristic of a regional gaming practice, but, nevertheless, the presence of a game box with squares adds two aspects of board design either unusual or particularly rare outside Nubia. Most of the gaming boxes known from antiquity are found in ancient Egypt [31] and, although this is certainly due to climatic conditions, their absence in late antiquity is equally salient. The presence of squares for the fields necessary on a Duodecim scripta board is similar to another board found in Nubia, a wooden example from Qustul.

\section{FUNERARY MATERIAL FROM QUSTUL, NUBIA}

In Qustul, located in Lower Nubia, north of Wadi Halfa, a now often-cited board of Duodecim scripta was excavated. The necropolis at Qustul, together with the one in Ballana nearby, were not part of the Meroitic Kingdom but date to a subsequent historical period in the region of Lower Nubia. They are found in present-day Egypt on the border with Sudan. In the words of Bruce Trigger: "...the transformation from the Meroïtic to the X-Group (Ballâna) culture 


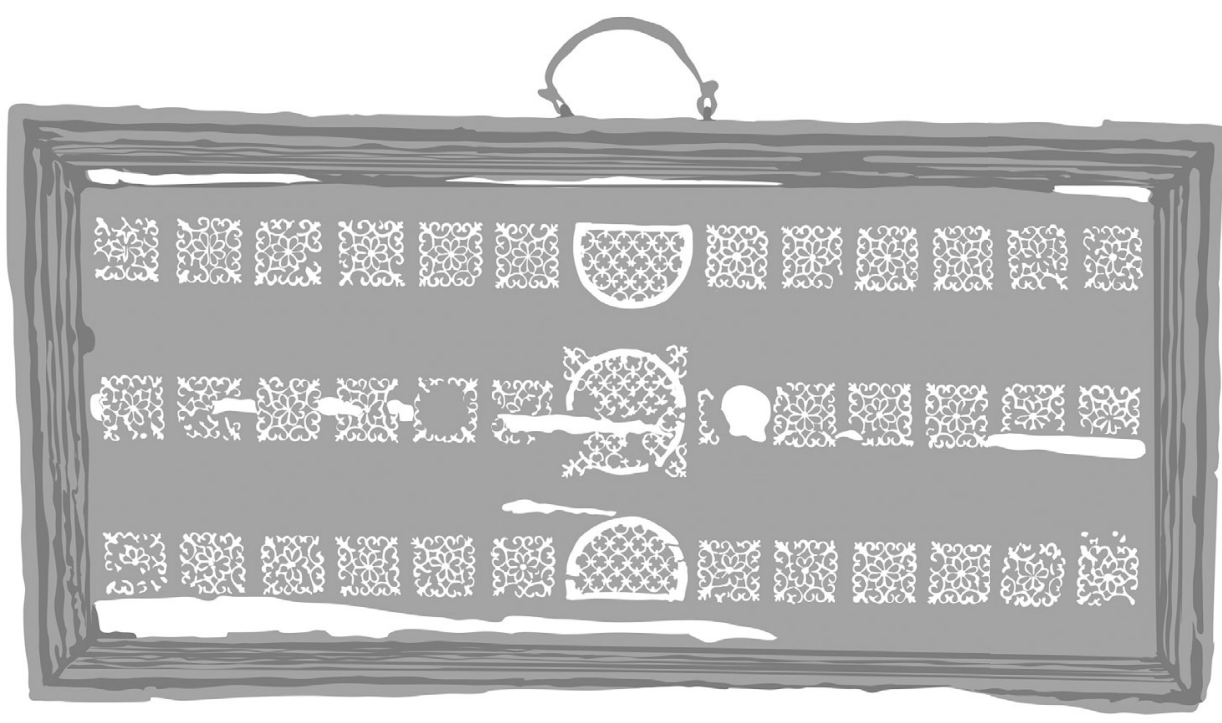

$<$ Figure 4. Drawing of the complete Duodecim scripta board from Qustul, Egypt. Drawing by Jennifer STEFFEY after EMERY \& KIRWAN 1938, pl. 87.

was a gradual one rather than a sharp break resulting from the occupation of the region by a new ethnic group" [32]. Walter Emery and Laurence Kirwan excavated the tombs in Qustul and Ballana in the early 1930s and these were "without doubt the most important monuments from this period in the whole of Lower Nubia" [33]. They are associated with the rulers of the time who rose to power after the collapse of the Meroitic Kingdom. The date for these cemeteries is still unclear but likely after the fourth and before the seventh century CE.

The board that was found intact, together with a bag of playing instruments, is one of the best preserved Duodecim scripta games in the archaeological record (fig. 4). The board has ivory squares as part of a rimmed wooden board with silver handles. The published description illustrates the riches that the board expresses: "The board is composed of a single piece of wood with a framed border, strengthened at the corners with silver brackets, attached with small silver nails. The [silver] loop handle is fastened to the frame with two silver gudgeon pins" [34]. The board was found face down on the surface at the side of the pit of Tomb 3 at Qustul. Underneath the board there was a leather bag with fifteen ivory and fifteen ebony playing pieces, five cube-shaped dice of ivory, and a dice tower or pyrgus of wood with silver fittings. The pyrgus was an original design with two carved dolphins on each side of the opening at the bottom. Its shape has been reconstructed from the fragments found in the leather bag.
This material was all found outside Tomb 3 at Qustul, a large structure that was more than fifty-three meters wide and almost ten meters high. It was robbed so that not all objects belonging to this tomb are known. Several objects, such as three glass lamp cups, were discovered near the robbers' passage but others, such as a silver jug, were found in the forecourt in front of the entrance to the tomb while several silver horse trappings and bronze bells were found with a large number of entombed animals [35]. The size of the tomb and the number of objects is overwhelming and still includes, even after its plundering in the past, a string of onyx barrel beads, an iron sword blade, a silver earring, a painted ivory comb, a silver vessel in the form of a water skin, to name but a few of the more valuable materials. For Tomb 3 alone there are 108 objects listed.

The game board and its associated materials were found outside the brick structure of the tomb and not anywhere near the robbers' passage. It was found close to but on the surface level rather than inside the tomb. Three iron knives with ivory and bone handles were also found in this area but not immediately associated with the game board itself [36]. They were all excavated and clearly belong to the period of the tomb. They also conform to the types of objects and fittings found inside the tomb. The authors explain: "Finally the pit and ramp were filled and a great earthen mound was raised over the tomb; in many cases offerings such as weapons, jewelry, vases, game etc., were buried in the mound" [37]. 
The latter comment by the authors is relevant as to how the materials just under the earthen mound were interpreted. Despite possibly being merely objects of daily use including furniture, cooking utensils, weapons and also tools to make them, they became an offering rather than things simply to be used by the deceased in the afterlife.

The situation is slightly different from Tomb 118 in Ballana. This tomb is equally sizeable with a fifty-four meter diameter and eight meter height. Only four bronze fittings were found in situ "what was probably a large gaming board made of wood and inlaid ivory" [38]. The size of the board can be roughly estimated at ninety by seventy centimeters as opposed to seventy-seven and a half by thirty-seven centimeters for the Qustul example. The object was located in the burial chamber underneath the bier. It makes the assumption of it being a gaming board problematic as there were no game pieces or dice found at all and its location was not in a chamber with utensils, weapons or food, but with the stand for the coffin. It suffices to state that not all wooden objects were preserved in these enormous mounds and that much material may have been lost due to plundering and climate conditions, including those game materials that employed precious metals.

\section{ROMAN DESERT FORTRESSES}

Most game boards in the archaeological record were scratched into a surface rather than preserved as three-dimensional objects. In Rome this may occur in marble or entire concrete tables may be manufactured, but in Sudan and Egypt such elaborate examples have not been uncovered. In Nubia, wooden game boards are the only evidence so far of Duodecim scripta, while in Roman Egypt they are mostly modestly carved on a rock surface with only an occasional example of a three-dimensional stone board.

At Abu Sha'ar game boards were made of the same stone as used for the construction of the towers and gates of the fort. According to Lynda Mulvin and Steven Sidebotham this was "a porous local gypsum prone to rapid decay" in this environment [39]. They were cut into regular rectangular blocks with playing fields carved into them. They conclude that they were well-carved but with neither intricate detail nor precious material. Some were reused as building blocks, some were thrown away or turned over in order to carve a game on the other side. The Duodecim scripta boards were part of a gaming room while the fortress was inhabited by Romans. It is more likely that these are examples of game boards made and used by Roman soldiers than games shared with the inhabitants of Roman Egypt.

The designs of the playing fields for the board at Abu Sha'ar, a part that may easily vary across regions and time, are of particular interest since all three boards attested had a slightly different appearance. Two had fields shaped as squares in three rows. A third board had rows of small holes of which only one outer and a center row were partly preserved; the holes in the outer row were joined by a set of small circles. One of the boards using squares had seven squares marked with a cross: two each in the other row and three such squares in the center row. They marked the middle of the board. The other board using squares designated the middle by connecting a square from each outer row and the middle row. The third example was not preserved enough to identify how the center of the board was indicated. All three were of a similar size, about thirty centimeters wide and, depending on the preservation, about sixty centimeters long. They attest to the fact that within the same players' community there is already variation of design, which, in this case, is unlikely to be a socio-cultural characteristic that points to appropriation and multiculturality.

In the Eastern desert of Egypt the excavation of Roman fortlets or praesidia revealed at least one partially carved Duodecim scripta board in Dawwi [40]. No size was reported but the design consisted of rows of small holes (See fig. 2). The board had a carved outer rim that may have been helpful when throwing dice or for keeping game pieces in place. It is a rare example of a carved stone board rather than an incision on a rock face. Only a small fragment was found in nearby Krokodilo. Charcoal traces of only four small holes and an outline of a center space were attested on a fragment measuring thirty by fifteen-and-a-half centimeters [41].

The boards in Abu Sha'ar date to the third or fourth century and the ones in the eastern desert to the second century CE. They are found in Eastern places of the desert and, while they attest that Roman soldiers played these games in Egypt, they do not help to elucidate an appropriation process on the part of the Egyptian population.

[38] Ibid., 153.

[39] Mulvin \& Sidebotham 2003: 604.

[40] BRUN 2003: 135, fig. 174.

[41] MATELLI, 2003, 594, 605, fig. 279. 


\section{KOM OMBO, EGYPT}

A number of game boards were part of a survey of graffiti inscriptions in Egypt conducted by Maria Nilsson and John Ward including four Duodecim scripta boards from the site of Kom Ombo [42]. The boards are located in the south-eastern part of the site in a corridor just outside the inner sanctuary of the temple. They are part of floor graffiti. Unlike Abu Sha'ar and Dawwi, this location was not exclusively occupied or built by Roman soldiers. It was a shared space and the practice of the game was known or at least witnessed by more people than just a group of Romans.

The four boards that were published all have a similar design of three rows of carved small holes, similar to the surface of the board from Dawwi. The main difference is found in how the center of the board is divided. In all four cases there are large brackets carved in the center of the board as if a space was being circumscribed for holding a cache of playing pieces (fig. 5). The design stands out as the brackets are particularly large and do not conform to known patterns or designs for Duodecim scripta boards elsewhere.

A fifth example (fig. 6) was documented as it was found next to demotic graffiti and the image of a canine as well as a foot. It shows a context of

[42] CRISt \& Dunn-VATURi \& DE VoOgt 2016.
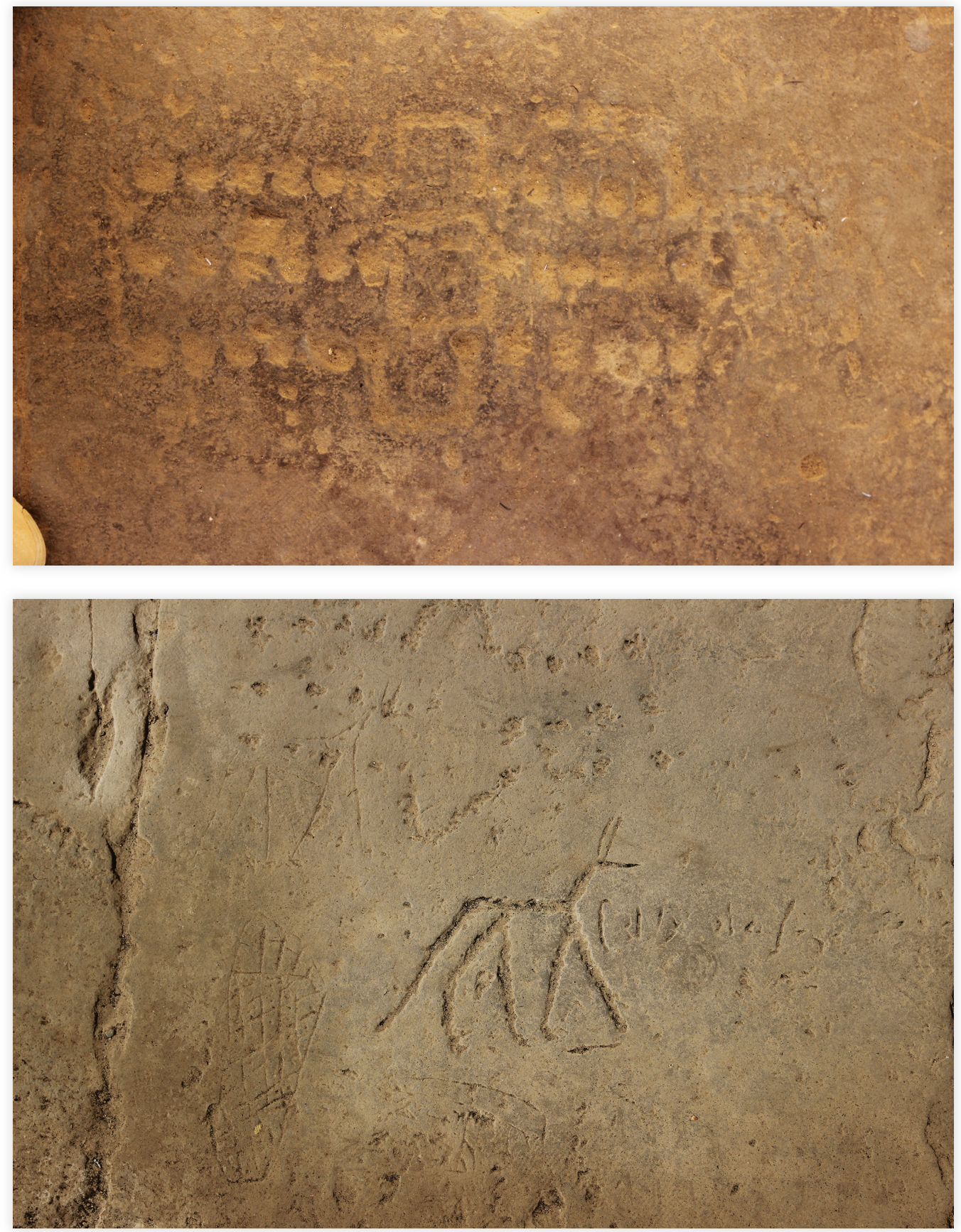

$<$ Figure 5

Duodecim scripta board from Kom Ombo, Egypt. Courtesy Maria NILSSON and John WARD.

\section{$<$ Figure 6.}

Duodecim scripta board in the context of other graffiti from Kom Ombo, Egypt. Courtesy Maria NILSSON and John WARD. 
graffiti rather than of games, which demonstrates that through the ages this floor was used repeatedly by visitors of the temple for this purpose. The game board seems to be unfinished as it is difficult to discern three rows of twelve playing spaces. Again the central part is marked with an enlarged space, in this case triangular. The playing spaces also seem to be placed at the far ends of these markings. As is often the case in Egypt, for instance with the roof at the temple of Khonsu at Karnak [43], pharaonic Egyptian and Roman markings are found side by side and this is true for games of even later periods as well [44]. Playing spaces are shared over time.

Where the boards in the Roman fortlets were exclusively associated with Roman soldiers, the boards at Kom Ombo blend into a world of graffiti games that is of all time periods. Their context confirms that in later periods games were played in similar environments and that places of play remained largely the same.

The only observation of these boards that stands out in comparison with other Duodecim scripta games recorded elsewhere is a local, i.e., Kom Ombo or perhaps Egyptian, tradition to mark the center of the board as enlarged spaces, appearing as imaginary handles of a portable board but more likely spaces for storing or aligning gaming pieces. Such a design difference is in line with the expectation that outer forms are more likely to change than abstract playing rules. Unfortunately, the cultural specificity or cultural significance of this particular element is limited without a further survey of other Egyptian sites, which have thus far not rendered examples of Duodecim scripta.

\section{TRACES OF APPROPRIATION: DESIGN AND CONTEXT}

In Roman Egypt and in the Meroitic Kingdom the game of Duodecim scripta was known and played. The traces are few with two or three boards documented for Nubia and a handful of games attested in the eastern desert of Egypt as well as a group at the site of Kom Ombo. But together they exemplify almost a full range of playable Duodecim scripta representations from wooden and stone boards to floor and rock-face graffiti. For the game to have reached the Meroitic Kingdom and to have become part of prestige goods in an elite grave presupposes that the playing practice was well-known throughout Egypt and not just Kom Ombo and a few remote army camps. Although few boards have been attested, the evidence is still rich in context and variety.
The variety of game board designs does not facilitate any generalization or even speculation about the appropriation of the board into Egyptian or Nubian practices of production. Nevertheless, the Nubian examples from Sedeinga and Qustul, which, for the sake of this argument, can be seen as part of a continuing playing tradition, are characterized by square playing fields of three rows with decorated fields indicating the center of the board. In both places the board is associated with fifteen playing pieces for each side as well as two or three cubic dice. The design of the squares is not unknown but also not typical elsewhere in the Roman world. Similarly, the Kom Ombo graffiti boards are consistently given three rows of small round playing fields with enlarged markings in the center of the board unlike those found in the Roman fortresses or any example found elsewhere in the Roman Empire. In short, it is possible to at least assume a process of appropriation when it comes to the design of Duodecim scripta playing boards in this region of the world.

The variation of Duodecim scripta representations is matched by the variation of contexts in which the game has been found in Egypt and Sudan. These elements usually go hand in hand. Wooden boards are mostly found in well-preserved offering or grave contexts while graffiti boards are more common in public areas with stone flooring. The burial contexts follow those found in Britannia and free Germania where elites are associated with the riches of a Roman game board. Again, this is not surprising as elite graves are more likely to have grave goods and rare materials that may still be recovered after two thousand years. But it does not take away the perceived significance of the game in these societies. The game boards are consistently found in the context of imported goods or otherwise rare or valuable items, apparently coveted by their owners. That board games are part of this elite context emphasizes their relevance in cultural exchange and cultural appropriation practices. These game boards are part of the pride and joy of being in contact with the Roman world [45].

[43] JACQUET-GORDON, 2003.

[44] CRist \& Dunn-Vaturi \& De Voogt 2016, for an overview.

[45] The author wishes to thanks Maria NILSSON, John WARD, Vincent FRANCIGNY and Jennifer STEFFEY for their generous help and for their permission to use the figures as illustration with this text. 
BEDON, Robert, 1989, « Les jeux de société chez les Romains », Archaeologia 246, p. 59-64.

BRUN, Jean-Pierre, 2003, «Dawwî », dans Hélène Cuvigny (éd.), La route de Myos Hormos. L'armée romaine dans le désert Oriental d'Égypte I, Le Caire, p. 133-136.

Crist, Walter \& Dunn-Vaturi, Anne-Elizabeth \& De Voogt, Alex, 2016, Ancient Egyptians at Play: Board Games Across Borders, London.

CRIST, Walter \& DE VOOGT, Alex \& DUNN-VATURI, Anne-Elizabeth, 2016, « Facilitating Interaction: Board Games as Social Lubricants in the Ancient Near East », Oxford Journal of Archaeology 35, 2, p. 179-196.

Cuvigny, Hélène, 2011, Didymoi. Une garnison romaine dans le désert Oriental d'Égypte I. Les fouilles et le matériel, Le Caire.

De Voogt, Alex \& Dunn-Vaturi, Anne-Elizabeth \& Eerkens, Jelmer, 2013, « Cultural Transmission in the Ancient Near East: Twenty Squares and Fifty-Eight Holes », Journal of Archaeological Science 40, p. 1715-1730.

De Voogt, Alex \& Francigny, Vincent \& BaAs, Pieter 2017, « Meroitic Graves With Roman Games: Elites Moving the Borders of Play », Zeitschrift der Deutschen Morgenländischen Gesellschaft 167, 1, p. 23-33.

EMerY, Walter B. \& KIRWAN, Laurence P., 1938, Mission Archéologique de Nubie 1929-1934. The Royal Tombs of Ballana and Qustul, I \& II, Cairo.

Finkel, Irving L., 2007, « On the Rules for the Royal Game of Ur », dans Irving Finkel (éd.), Ancient Board Games in Perspective: Papers From the 1990 British Museum Colloquium, With Additional Contributions, London, p. 16-32.

JACQUET-GoRDON, H., 2003, The graffiti on the Khonsu temple roof at Karnak: a manifestation of personal piety. Oriental Institute Publications 123, Chicago.

Jensen, Xenia Pauli, 2009, « From Fertility Rituals to Weapon Sacrifices: the Case of the South Scandinavian Bog Finds », dans Uta von Freeden \& Herwig Friesinger \& Egon Wamers (éd.), Glaube, Kult und Herrschaft: Phänomene des Religiösen im 1. Jahrtausend n. Chr. in Mittel- und Nordeuropa, Bonn, p. 53-66.

Jensen, Xenia Pauli, 2013, «Imitation and Transformation: Roman Militaria in South Scandinavian Grave Finds » dans Mirjana Sanader \& Ante Rendić-Miočević \& Domagoj Tončinić \& Ivan Radman-Livaja (éd.), Proceedings of the XVI ${ }^{\text {th }}$ Roman Military Equipment Conference: Weapons and Military Equipment in a Funerary Context, Zagreb, p. 177-183.

KRÜGER, Thomas, 1982, Das Brett- und Würfelspiel der Spätlatènezeit und römischen Kaiserzeit im freien Germanien, Neue Ausgrabungen und Forschungen in Niedersachsen 15, Hildesheim.

LECLANT, Jean, 1966, « Fouilles et travaux en Égypte et au Soudan, 1964-1965 », Orientalia 35, p. 161-165.

MATELlY, A., 2003, «Small objects », dans Hélène Cuvigny (éd), La Route de Myos Hormos : I'armée romaine dans le désert oriental d'Égypte, Praesidia du désert de Bérénice, Volume II. Cairo, Institut français d'archéologie orientale.

MAY, Roland, 1992, « Les jeux de table en Grèce et à Rome », dans Roland May et al. (éd.), Jouer dans l'Antiquité, Marseille, Musée d'Archéologie méditerranéenne, Centre de la Vieille Charité, 22 novembre 1991-16 février 1992, Paris, RMN, p. 166. Mulvin, Lynda \& Sidebotham, Steven E., 2004, «Roman Game Boards From Abu Sha'ar (Red Sea Coast, Egypt) », Antiquity 78, p. 602-617.

RIECHE, Anita, 1984, Römische Kinder- und Gesellschaftsspiele, Stuttgart.

SCHÄDLER, Ulrich, 1998, « Mancala in Roman Asia Minor », Board Games Studies 1, p. 10-25.

SCHÄDLER, Ulrich, 2000, «Late-antique Gaming Table at the Baths of Hadrian at Aphrodias », Board Games Studies 3, Cover photograph.

SCHÄDLER, Ulrich, 2012, « Miroir avec scène de jeu de plateau », dans Isabelle Bardiès-Fonty \& Anne-Elizabeth Dunn-Vaturi (éd.), Art du Jeu, Jeu dans l'Art, Paris, p. 20-23.

SchÄDLER, Ulrich, 2007, «The Doctor's Game: New Light on the History of Ancient Board Games », dans Philip Crummy (éd.), Stanway: An élite burial site at Camulodunum, Oxford, p. 359-375.

SCHÄDLER, Ulrich, 1995, «XII Scripta, Alea, Tabula: New Evidence for the Roman History of "Backgammon" » dans Alex de Voogt (éd.), New Approaches to Board Games Research: Asian Origins and Future Perspective, Leiden, p. 73-98.

SCHÄDLER, Ulrich, 2013, «Une table de jeu miniature », Archéothéma 31, p. 23.

Schiff, Grorgini, Michela, 1966, « Sedeinga 1964-1965 », Kush 14, p. 244-261.

Schulz, Walther, 1953, Leuna: Ein germanischer Bestattungsplatz der spätrömischen Kaiserzeit, Berlin.

StJeRnquist, Berta, 1998, « The Basic Perception of Religious Activities at Cult-Sites Such as Springs, Lakes and Rivers », dans Lars Larsson \& Berta Stjernquist (éd.), The World-View of Prehistoric Man, Stockholm, p. 158-178.

TöRök, László, 2009, Between Two Worlds: The Frontier Region Between Ancient Nubia and Egypt 3700 BC-500 AD, Leiden. TöRöK, László, 2011, Hellenizing Art in Ancient Nubia, 300 BC-AD 250, and its Egyptian Models: A Study in "Acculturation", Leiden.

TRIGGer, Bruce. C., 1969, « The Royal Tombs at Qustul and Ballâna and their Meroïtic Antecedents », The Journal of Egyptian Archaeology 55, p. 117-128. 